\title{
Aggressive Digital Papillary Adenoma
}

National Cancer Institute

\section{Source}

National Cancer Institute. Aggressive Digital Papillary Adenoma. NCI Thesaurus. Code C162848.

An eccrine sweat gland adenoma with aggressive local growth. Most cases present as nodular lesions on the digits. It is characterized by the presence of tubular and ductal structures with areas of papillary projections into cystic lumina. 